\title{
再婚からみるライフコースの変容
}

\begin{abstract}
余田翔平
要 約

本稿では，再婚率の（1）趨勢，（2）階層差，（3）趨勢変化の階層差に着目して記述的分析を行っ た。『日本版総合的社会調查（JGSS）』にイベントヒストリーモデルを適用した結果，以下の知見が得 られた。第 1 に, 近年の離死別コーホートほど, 再婚八ザードは低下している. 第 2 に, 男性よりも 女性のほうが, 低学歴層よりも高学歴層のほうがそれぞれ再婚経験率が高い. 第 3 に, 学歴と再婚経 験との正の関連は近年の離死別コーホートほど明確に現れており，一方で再婚経験率の性差は縮小傾 向にある.

以上を踏まえると，日本社会では「離死別者の非再婚化」が進展しており，未婚化・晚婚化のトレ ンドとあわせて考えれば，無配偶の状態に滞留するリスクがライフコースを通じて高まっていると推 測される，さらに，こうしたライフコースの変化は社会全体で一様に広がっているわけではなく，階 層差を伴っている.
\end{abstract}

キーワード：再婚, ライフコース, 社会階層

2014, 家族社会学研究, 26(2)：139-150

\section{Remarriage and Changes in Life Course Patterns}

\section{Shohei Yoda}

\begin{abstract}
This study utilizes data from the Japanese General Social Survey (2000-2002) to measure trends in remarriage rates by gender and educational level. Event history analysis reveals the following findings. First, the probability of remarriage has declined among recent cohorts entering singlehood due to either divorce or widowhood. Second, the likelihood of remarriage depends on gender and educational level. Men are more likely to get remarried than women, and the more educated have a higher probability of remarrying than the less educated. Third, the educational differentials in remarriage rates have increased across the cohorts, whereas the gender gap has decreased.

Past studies have seen a rapid decline in first marriage rates and an increase in divorce rates. Given the demographic trends, the results of the present study imply that Japanese people face an increased risk of singlehood across their life course. The changes, however, are concentrated among socioeconomically vulnerable groups.
\end{abstract}

Key words: remarriage, life course, social stratification

2014, Japanese Journal of Family Sociology, 26(2): 139-150

よだ しょうへい：国立社会保障・人口問題研究所

National Institute of Population and Social Security Research, Hibiya Kokusai Building 6th Floor, 2-2-3 Uchisaiwaicyo, Chiyoda-ku, Tokyo 1000011, Japan

E-mail: yoda-shouhei@ipss.go.jp 
投稿論文：再婚からみるライフコースの変容

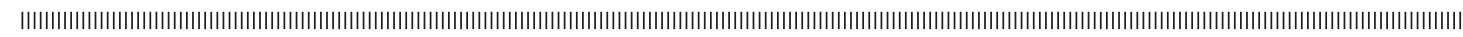

\section{I. 研究の背景と目的}

戦後日本社会において, 人々の婚姻行動・婚姻 歴に大きな変化が生じていることは周知のとおり である．婚姻関係の形成に関する最も大きな変化 のひとつは, 未婚化・晚婚化の進展であろう。一 方, 婚姻関係の解消については, 平均寿命の伸長 により結婚後の早い段階で配偶者との死別を経験 する人々は少なくなったものの, 離婚を経験する 人々は増加しているといった変化が見られる.

婚姻行動をめぐるこうした変化が実証されてき た中で, 十分に明らかにされていない部分が「再 婚」である、日本の家族社会学では，家族のあり ようが大きく変化し多様化していること，すなわ ち「家族の多様化」（目黒 1987; 野々山 1996）が 主張されてきた。 その中で, 初婚のみならず再婚 による夫婦形成が増加していることは「多様化」 の証左のひとつとして考えられてきた ${ }^{(1)}$. 図 1 は, 初婚一再婚別に見た婚姻件数ならびに総数に 対する再婚割合である。後者は，夫妻のそれぞれ 一方から見た再婚の割合を指す（すなわち配偶者 の初婚-再婚の区別はしていない). 1970 年代半 ばから初婚件数が低下傾向に向かう一方, 再婚件 数は徐々にではあるが増加している.夫／妻とい う個人単位で見ても再婚の占める割合は増加して おり, 2010 年では $5 \sim 6$ 人に 1 人の結婚が初婚で
はなく再婚である.

このように，再婚によって婚姻関係が形成され ることはもはや珍しいことではない.しかし，こ のことは直ちに, 個人がライフコースを通じて再 婚を経験しやすくなった，言い換えると複数回の 結婚を経験するようになった，ことを示すもので はない，仮に個人にとっての再婚の発生率に変化 がないとしても, 図 1 に見られる変化は生じう る。なぜなら, 離婚の増加によって再婚のリスク 人口（再婚を経験する可能性を持った人々からな る集団，すなわち離死別者）が拡大すれば，個人 にとっての再婚の起こりやすさに変化がなくと も，社会全体で見れば再婚がより多く観察される ようになるためである.したがって, 図1のよう なマクロレベルのデータから個人のライフコース の変化を推測することは難しい(2).

そこで本稿では, 次の 3 つの問いに答えること を目的とする。第 1 の問いは「人々は再婚を経験 しやすくなったのか」である，換言すれば，再婚

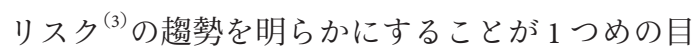
的である. 具体的には, 離死別コーホート間の再 婚率の差異に着目する。第 2 の問いは「誰が再婚 しやすいのか」である。再婚リスクの集団間格 差・階層差については, これまで基礎的な分析が ほぼなされていない。本稿では, 再婚リスクの学 歴間格差とジェンダー間格差を取り上げる．第 3

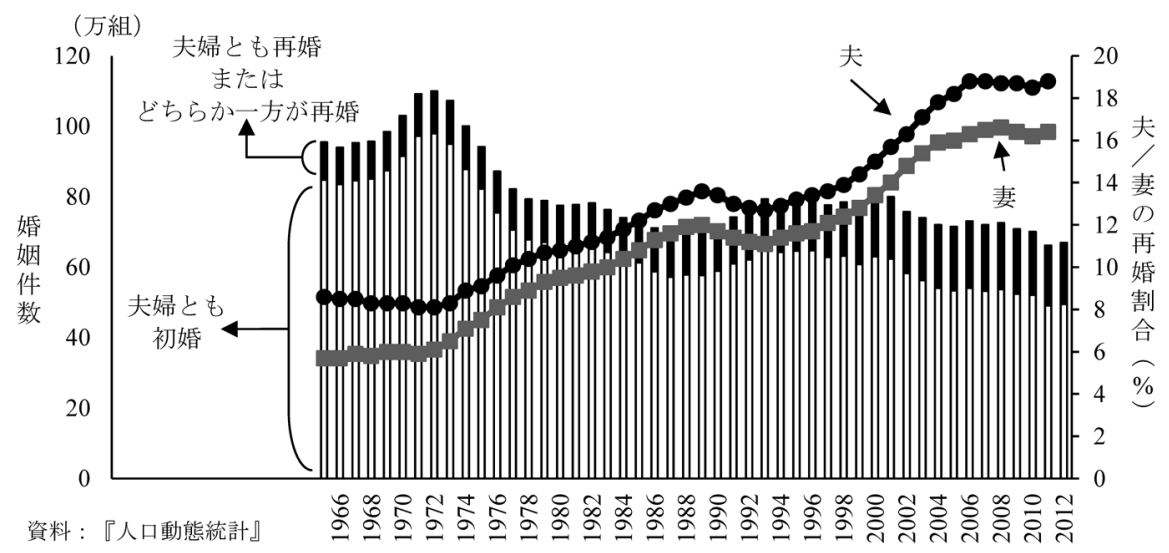

図 1 初婚-再婚別に見た婚姻件数および総数に対する再婚割合 


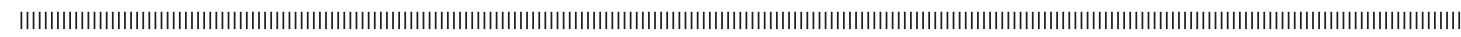

の問いは,「誰が再婚しやすく（しにくく）なっ たのか」である。つまり，再婚リスクの趨勢に変 化が見られたとしたら，そうした変化は社会全体 に均一に広がってきたのか，それとも特定の層に 集中して生じてきたのかを明らかにする。このよ うに，本稿の目的は，再婚リスクの記述的分析を 行うことにある，再婚リスクの趨勢変化や階層差 が確認された場合には,「なぜそのような傾向が 見られるのか」という説明に踏み込んだ分析が当 然求められることになるが，それについては稿を 改めて論じたい。本稿では，再婚という，これま で焦点があてられることが少なかったライフコー スの側面について，その趨勢と階層差の基礎的な 知見を提示することを目的とする.

本稿の構成は以下のとおりである. 2 章では, 婚姻歴にかかわるライフコースの変化について, 先行研究の知見を整理する．3 章では使用する データ・変数・分析方法について説明し，4 章で 分析結果を提示する. 5 章では分析結果を踏まえ て, 日本社会の中で婚姻パターンにいかなる変容 が生じているのかを議論する.

\section{II. 先行研究の整理と本稿の位置づけ}

本節では，婚姻行動に関する先行研究の知見を 整理し, 本稿の研究上の位置づけを示す.

個人の婚姻歴は,「無配偶」と「有配偶」とい う 2 つの状態の間の移行の繰り返しとして捉える ことができる。無配偶から有配偶への移行は初 婚・再婚を意味し, 反対に有配偶から無配偶への 移行は離別や死別によってもたらされる。このう ち，配偶者と早期に死別するリスクは，産業化に よる経済水準の向上に伴って低下していく，その ため，現代日本社会において若年期から中年期の 婚姻パターンを考察するうえでは, 初婚, 離婚, 再婚の 3 つの要素が重要になってくる(4)。この中 で, 初婚と離婚についてはミクロデータを用いた 実証研究が蓄積されてきた，以下では，それらの 研究の知見を要約していく.

まず，言うまでもなく初婚イベントの発生リス
クは低下しており, 多くの人々が未婚無配偶の状 態にとどまる傾向が強くなっている。また，初婚 行動と社会経済的地位との間には, 明確な関連が 存在することが多くの実証研究から明らかにされ ている，例を挙げると，「第 1 回全国家族調査 （NFRJ98）」を用いた加藤（2001）によれば，高 学歴男性は低学歴男性よりも，そして低学歴女性 は高学歴女性よりも結婚しやすい(5)。また，「結 婚と家族に関する国際比較調査（JGGS）」を分析 した津谷（2009）では，男性の間では正規雇用者 が，女性の間では低学歴者がそれぞれ初婚八ザー ドが高いことが確認されている。そして，このよ うな初婚経験率の階層差の趨勢については, 経済 成長率の低下に伴って階層差が拡大しているとい う主張（加藤 2001, 2004）が存在する一方で, 学 歴間格差は出生コーホート間で安定的であるとい う結果（白波瀬 1999）も得られており，やや知 見が混在している.

つぎに，離婚について言えば，ミクロデータを 用いた実証研究からも，個人が離婚を経験するリ スクは高まっていることが確認されている.さら に,これらの先行研究の中では離婚リスクの階層 差も検討されており, 離婚リスクは低所得・低学 歴層に高い（加藤 2005; 福田節也 2005）。加え て，そうした離婚リスクの階層差は近年の結婚 コーホートほど拡大する傾向にある（福田亘 孝 2009）ことなどが明らかにされてきた。

以上の知見を整理すれば，日本において個人の 婚姻歴に生じている変化のひとつは，「無配偶期 間の長期化」と言える。初婚リスクの低下は未婚 無配偶の状態が継続することを，離婚リスクの上 昇は有配偶の期間が短縮することをそれぞれ意味 するためである.

ただし，「無配偶期間の長期化」という知見は, あくまで初婚と離婚に関する研究から導き出され る結論である。婚姻歴全体を俯瞰したときにもこ の知見が当てはまるか否かは，再婚に関する分析 結果を待つ必要がある(6)。なぜなら, 再婚リスク の趨勢の「向き」によって, 婚姻パターンの変化 
投稿論文：再婚からみるライフコースの変容

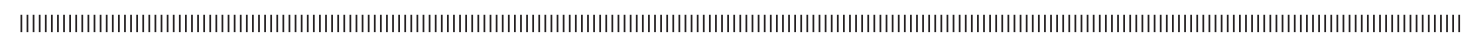

について異なる結論に至るためである，再婚リス クが高まっているとすれば, 人々は離死別によっ て無配偶になったとしても再婚を通じて有配偶の 状態に戻りやすい。この場合, 初婚タイミングの 遅れによって無配偶期間が長期化しているにせ よ, 初婚後の婚姻歴においては必ずしも無配偶期 間が長期化しているわけではない。他方で, 再婚 リスクが低下しているのであれば, 人々は離死別 後に無配偶の状態にとどまりやすくなる．この場 合は, 婚姻歴全体で無配偶期間が長期化している ことになる.

さらに, 既存研究では婚姻行動（初婚・離婚） の社会経済的格差が指摘されてきたが, 再婚行動 についても同様の知見が当てはまるのであろう か. 言い換えれば, 再婚の機会は個人の社会経済 的資源の多寡に依存するのだろうか. 本稿では, 社会経済的地位の代理指標として学歴を取り上 げ，再婚リスクとの関連を検討する。加えて，再 婚リスクのジェンダー間格差に着目することも重 要である. 男性に比して女性は離婚後に生活水準 が悪化することが知られている（Peterson 1996; Tanaka 2013)。その理由としては，女性は結婚・ 出産によるキャリアの中断を経験しやすいこと， 離別後に子どもを引き取るのは一般的に女性であ る（すなわち，父子世帯よりも母子世帯のほうが 形成されやすい）ことなどが挙げられる。その 結果, 母子世帯の貧困率は極めて高い（阿部 2008）。こうしたなか, 離死別した女性にとって, 再婚は貧困・低所得から脱却するひとつの経路に なりうる。

最後に, 再婚リスクの趨勢に何らかの変化が見 られるとすれば，そうした変化は社会全体に一様 に広がってきたのだろうか, それとも特定の階層 に集中してきたのだろうか. 先述のとおり, 既存 研究では初婚や離婚の趨勢には階層による差異が 存在することが指摘されてきた。再婚にも同様の 傾向が確認されるのであれば，それは婚姻行動 （あるいは婚姻パターン）が階層的地位によって 分化していくことを意味する.
再婚リスクの趨勢や階層差を検討した国内の研 究は極めて少ないものの,「全国調査『戦後日本 の家族の歩み』(NFRJ-S01)」を用いた福田亘孝 （2009）や「日本版総合的社会調査（JGSS）」を用 いた永井（2010）がある. 福田亘孝（2009）では, 近年の離死別コーホート, 高学歴層, 離死別 1 年 後に正規雇用・パート就労, 離死別時に未成年の 子どもあり，などの属性が高い再婚率と結びつい ていると述べられている，一方，永井（2010）で は, 男女ともに離死別時年齢が若いほど再婚経験 率が高いこと, 女性のみ離死別時に子どもがいる ことが再婚経験に負の影響を持つことなどが報告 されている.

いずれの研究も再婚に着目した貴重な研究であ るものの，いくつかの限界も指摘できる．福田亘 孝（2009）はデータの制約上, 再婚の時期がわか らないため, 再婚経験の有無と共変量との二重ク ロス集計にとどまっている，加えて，分析対象は 女性に限定されている。 また，永井（2010）は本 稿と同じくJGSS を使用しているが, 離死別経験 者を対象に, 再婚経験を従属変数にした二項口 ジットモデルを適用している。このように既存研 究では, データや分析方法の性質上, 右センサー された個体の情報が十分に活かされていない.

以上を踏まえ, 本稿では婚姻歴データを活用 し，はじめに再婚リスクの趨勢の「向き」(上 昇／安定／低下）を特定する，つづいて再婚リス クの階層差を検討し, そして最後に, 階層によっ て再婚リスクの趨勢に差異があるのかを明らかに していく.

\section{III. データと方法}

\section{1. データ}

以下で使用するデータは,「日本版総合的社会 調査（JGSS）」の 2000 年, 2001 年, 2002 年の 3 時 点の調査の累積データ (以下, JGSS2000-2002 と 表記）である。これら各年次の調査では, 調査時 点の婚姻上の地位に加え, 初婚・離婚・死別・再 婚それぞれの経験の有無と経験時年齢など，婚姻 


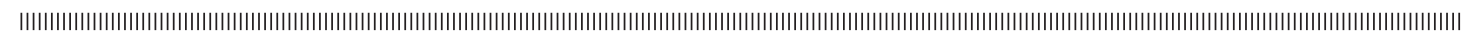

歴に関する詳細な質問が含まれている。

JGSS2000-2002 を用いた再婚の分析にはメリッ トとデメリットとがある。メリットは，パネル調 査と比較した際, 再婚リスクの長期的趨勢の検討 に適していることである，パネル調査の場合，観 察期間が極めて長い場合を除いて，再婚のリスク 開始時点（離死別年）は個体間で大きく変わらな い.たとえば, 10 年間のパネルデータであれば, 離死別年のレンジは最大でも 10 年にしかならな い(7). 他方で JGSS2000-2002 は，婚姻歴を回顧的 に尋ねているため，離死別のタイミングが多様な 回答者に対して再婚の生起を追うことができる。 そのため, 再婚の趨勢分析にはパネルデータより も JGSS2000-2002のほうが向いていると言える. 一方で JGSS2000-2002 を用いることのデメリット は, 時間依存する共変量が限定されることであ る。たとえば, JGSS2000-2002には職歴データは 含まれておらず, 収入も調査時点のものしか把握 できない，そのため, 離死別後の職業や収入の変 動が再婚の起こりやすさにどれほど影響を及ぼす のかといった点は検討できない.

分析対象は次のように設定した。まず，再婚の リスクセット（離死別者）を可能な限り確保する ことを考慮し，1940 年から 1999 年の間に配偶者 との離死別を経験した回答者を分析対象とし た ${ }^{(8)}$. さらに, 離死別時年齢が 65 歳未満の回答 者に限定している。これは本稿の関心が, 高齢期 ではなく，若年期から中年期に生じた離死別の後 に人久が再婚するか否かに関心があるためであ る. 最後に, 回答者にとっての 1 回目の再婚の生 起のみを分析対象とし, 2 回目以降の再婚は分析 から除外する。ここで確認しておきたいのは， （JGSS では配偶者が初婚か再婚かはわからない が）回答者が初婚・配偶者が再婚の場合, その結 婚は「再婚」とみなされないことである。本稿が 分析対象とするのはあくまで個人にとっての 2 回 目の結婚（=1 回目の再婚）の生起であり,「再 婚世帯の形成」ではないためである。

\section{2. 変数と分析方法}

独立変数は離死別年, 性別, 学歴の 3 つであ る. 離死別年は, 再婚リスクの趨勢を検討するた めに用いる。後述するカプランマイヤー法では 1940-59 年（89）/1960-79年（253）/1980-99年 （536）の 3 つの離死別コーホート（カッコ内の数 值はケース数）に分類して用いるが, 多変量解析 では連続変数として扱う。学歴は，中学／高校／ 大学（短大含む）の 3 カテゴリーである。性別に ついては, 女性を 1 とするダミ一変数を作成し た。

そのほかに統制変数として, 離死別時の回答者 年齢, 無配偶になった理由（離別か死別か），初 婚年齢，離死別時の末子年齢を用いる。さらに， リスク継続年数（離死別後の経過年数）の効果を 表すダミ一変数を作成した。これらのダミ一変数 は，再婚ハザードの時間依存を表現するために用 いられる。

以上の使用変数に欠損值を含む個体を除外した 結果, 分析対象者は 878 名, 再婚の発生件数は 218 であった。分析に使用する変数の記述統計量 は表 1 のとおりである. 変数の分布について 2 点 触れておく、第 1 に, 女性が $70.7 \%$ と多数派を占 めるのは，女性のほうが死別を経験しやすいため である。第 2 に，分析対象者の $41.5 \%$ の最終学歴 が中学であるが，これは分析対象の出生コーホー トが比較的古いことを考慮すれば極端に高い数字 ではない ${ }^{(9)}$ 。ただし，離婚リスクが低学歴層に高 いことを踏まえれば，再婚イベントのリスクセッ トに含まれる回答者は相対的に低学歴層に偏って いると考えるべきであろう。

分析方法はイベントヒストリーモデルを採用 し，具体的には以下の手順で進めていく．はじめ に，カプランマイヤー法によって生存関数を推定 し, 離死別コーホート・性別・学歴によって再婚 の累積経験率がどのように異なるのかを視覚的に 検討する。つぎに，複数の要因を同時に考慮した うえで再婚ハザードを推定するために，離散時間 ロジットモデルを用いる。離散時間ロジットモデ 
投稿論文：再婚からみるライフコースの変容

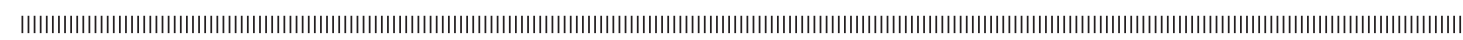

表 1 記述統計量 $(N=878)$

\begin{tabular}{|c|c|c|}
\hline 再婚経験 & $\begin{array}{l}\text { あり } \\
\text { なし }\end{array}$ & $\begin{array}{l}24.8 \% \\
75.2 \%\end{array}$ \\
\hline 性別 & $\begin{array}{l}\text { 男性 } \\
\text { 女性 }\end{array}$ & $\begin{array}{l}29.3 \% \\
70.7 \%\end{array}$ \\
\hline 離死別時年齢 & $\begin{array}{l}30 \text { 歳未満 } \\
30 \sim 39 \text { 歳 } \\
40 \sim 49 \text { 歳 } \\
50 \text { 歳以上 }\end{array}$ & $\begin{array}{l}22.1 \% \\
26.1 \% \\
20.5 \% \\
31.3 \%\end{array}$ \\
\hline 学歴 & $\begin{array}{l}\text { 中学 } \\
\text { 高校 } \\
\text { 大学 }\end{array}$ & $\begin{array}{l}41.5 \% \\
44.1 \% \\
14.5 \%\end{array}$ \\
\hline 無配偶になった理由 & $\begin{array}{l}\text { 離別 } \\
\text { 死別 }\end{array}$ & $\begin{array}{l}45.2 \% \\
54.8 \%\end{array}$ \\
\hline 離死別時の末子年齢 & $\begin{array}{c}\text { 子どもなし } \\
0 \sim 5 \text { 歳 } \\
\text { 6〜 } 15 \text { 歳 } \\
16 \sim 19 \text { 歳 } \\
20 \text { 歳以上 }\end{array}$ & $\begin{array}{r}22.1 \% \\
22.3 \% \\
19.7 \% \\
8.2 \% \\
27.7 \%\end{array}$ \\
\hline 離死別年 ${ }^{\text {a) }}$ & & $1980.9(14.5)$ \\
\hline 初婚年齢 a) & & $24.2(3.7)$ \\
\hline
\end{tabular}

a)平均値（標準偏差）

ルの推定にあたっては, 離死別を経験してから再 婚するまでの各年を1レコードとするパーソンイ ヤーデータを作成した。調査時点までに再婚を経 験していない回答者は観察打ち切り（右セン サー）となる。また, 離死別から 20 年以内に再 婚しなかった場合もその時点で観察打ち切りとし た。なお，イベントヒストリーモデルの詳細につ いては, Yamaguchi (1991) などを参照されたい.

ここで, 分析方法に関する注意点として 2 点述 ベておく，第 1 に，以下の分析は男女に分割せず に行う. 初婚の分析は男女別に行われることが一 般的であるが，本稿の関心のひとつは再婚経験の 性差にあるので, 男女込みのデータセットを用い る.この場合, 主効果のみのモデルでは, 再婚の 生起に対する共変量の効果は男女間で同一という 仮定を置くことになる，再婚の規定要因が性別に よって異なる可能性は十分考えられるが, 本稿で はむしろ, そうした共変量の効果の性差を交互作
用項によって抽出するという手続きを取る.

第 2 に, 本稿の分析は, 厳密には「婚姻パター ン」の分析にはなっていない.「II. 先行研究の 整理と本稿の位置づけ」で述べたように, 本稿の 問題関心のひとつは，無配偶期間の長期化が進展 しているのかという点にある。この問いに対し て, 本稿では, 再婚の分析から得られた知見と, 初婚・離婚に関する先行研究の知見とをつなぎ合 わせて, 婚姻パターンの変化について結論を導く という手順を取る。しかし，婚姻パターンとは婚 姻歴全体を見渡したときに複数のイベントの連鎖 で表現される「配列」を指すため，本来は婚姻歴 全体の情報を可能な限り一度に分析するような方 法のほうが望ましい。こうした分析を可能にする 方法のひとつとして, 最適マッチング法（渡 邊 2004; 福田亘孝 2006）などが考えられる。し かし，本稿では再婚イベントに関する基礎的分析 を行うことを優先させ，婚姻歴の配列に着目した 分析については今後の課題としたい.

\section{IV. 結 果}

\section{1. カプランマイヤー法による再婚率の比較}

はじめに, カプランマイヤー法を用いて, 離死 別後の時間経過に伴う再婚の累積経験率をグルー プ間で比較する。結果は図 2 に示した。まず，離 死別コーホートについて見ると，最も古い194059 年コーホートにおいて, 再婚の経験率が最も 高いことがうかがえる。より最近の離死別コー ホート（1960-79年コーホート，1980-99年コー ホート）では，再婚の経験率は低下傾向にある. 1940-59年コーホートのサンプルサイズは 89 と かなり小さいため, コーホート間の差異について は慎重になるべきであるけれども，少なくとも， 近年離死別によって無配偶になった人々の間で再 婚率が上昇している様子は見受けられない。

つづいて，性別について見てみよう。ここで は, 女性よりも男性のほうが再婚しやすいという 結果が明確に表れている。再婚率に性差が存在す ることはマクロ統計からもよく知られた事実であ 


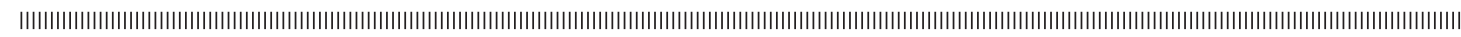
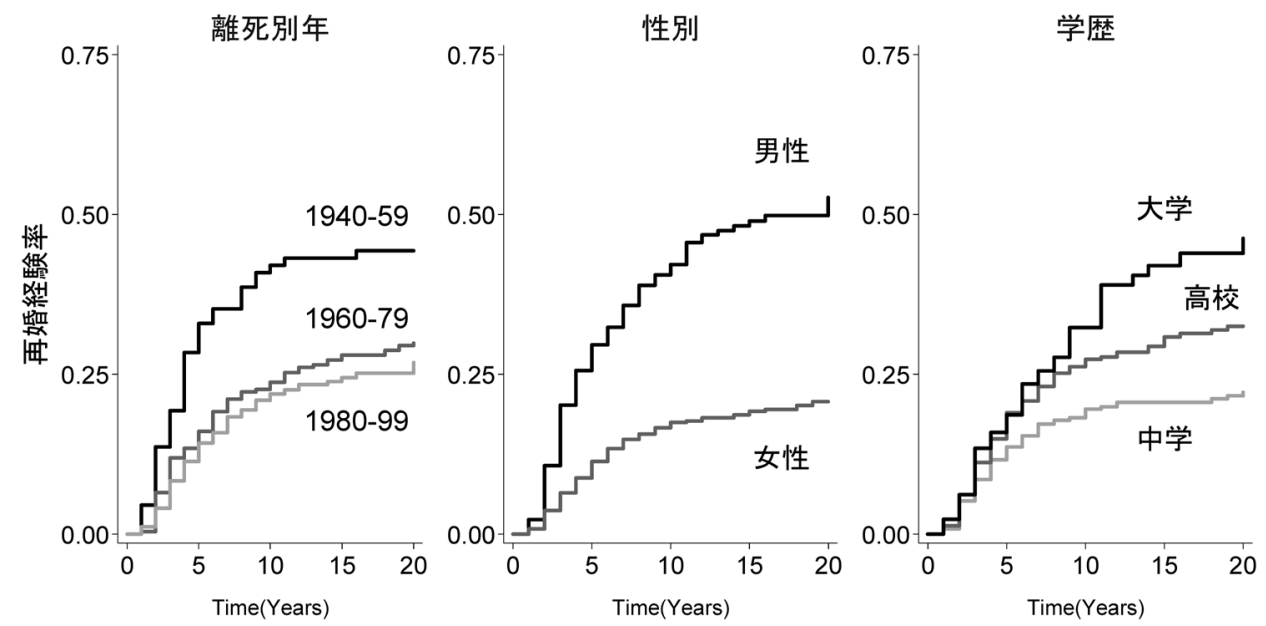

図 2 カプラン・マイヤー法による再婚の累積経験率の推定

るが, 同様の傾向が JGSS データでも確認された ということになる。

最後に, 学歴と再婚率との関連について見る と, 再婚の累積経験率は「大学」で最も高く, 「中学」で最も低い。したがって，低学歴層より も高学歴層のほうが再婚しやすいという結果が得 られている。

以上の結果を踏まえると, 再婚率の趨勢につい ては近年に離死別した人々が再婚しにくいという 傾向が, 再婚率の階層差については男性や高学歴 者が再婚しやすいという傾向がそれぞれ見られ る。ただし，これらはあくまで共変量と再婚率と のゼロ次の関連である，そこでつぎに，離散時間 ロジットモデルによる分析に進む．

\section{2. 離散時間ロジットモデル}

表 2 は離散時間ロジットモデルの推定結果であ る.

モデル 1 は, リスク継続年数, 性別, 離死別 年, 学歴, その他統制変数を投入した主効果のみ のモデルである。なお, 離死別年は平均值で中心 化している，再婚ハザードの時間依存はここでの 主たる関心ではないが，リスク継続年数の係数を 見ると, 離死別後 3 年目あたりをピークにその後 は再婚八ザードが低下していくことがわかる ${ }^{(10)}$. その他の統制変数についても見ておくと，まず，
離死別時年齢や初婚年齢が若いほど再婚ハザード が高い。また，無配偶になった理由が死別よりも 離別のほうが再婚しやすい. 最後に, 離死別時の 末子年齢の効果はやや複雑であり，「子どもなし」 と比較して，「末子 $6 \sim 15$ 歳」は再婚八ザードが 有意に低く，一方で「末子 16 19 歳」「末子 20 歳以上」では再婚ハザードが有意に高い。離死別 時の末子年齢のこうした非線形の効果は，思春期 に差し掛かる子どもがいる場合には再婚が控えら れることを意味しているのかもしれない。

それでは，本稿の主たる関心事である，性別， 離死別年, 学歴の効果はどうであろうか. 女性ダ ミーの係数はマイナスに有意であり，モデル内の 他の変数を統制してもなお, 男性と比較して女性 は再婚ハザードのオッズが $0.31\left(=e^{-1.157}\right)$ 倍とな ることがわかる．離死別年の係数はマイナスに有 意であり，近年離死別を経験した人ほど再婚しに くいことが改めて確認された。他方で, 学歴の 主効果は有意ではなく, このモデルからは学歴 によって再婚ハザードに差異があるとは言えな い.

しかし, 学歴の効果は性別によって異なる。モ デル 2 では, 性別と学歴との交互作用項を追加し たところ, 有意な効果を示している.このモデル の学歴の主効果に着目すると, 高校ダミーが 
投稿論文：再婚からみるライフコースの変容

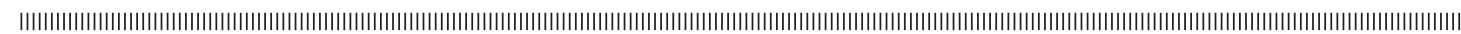

表 2 再婚の生起に関する離散時間ロジットモデル

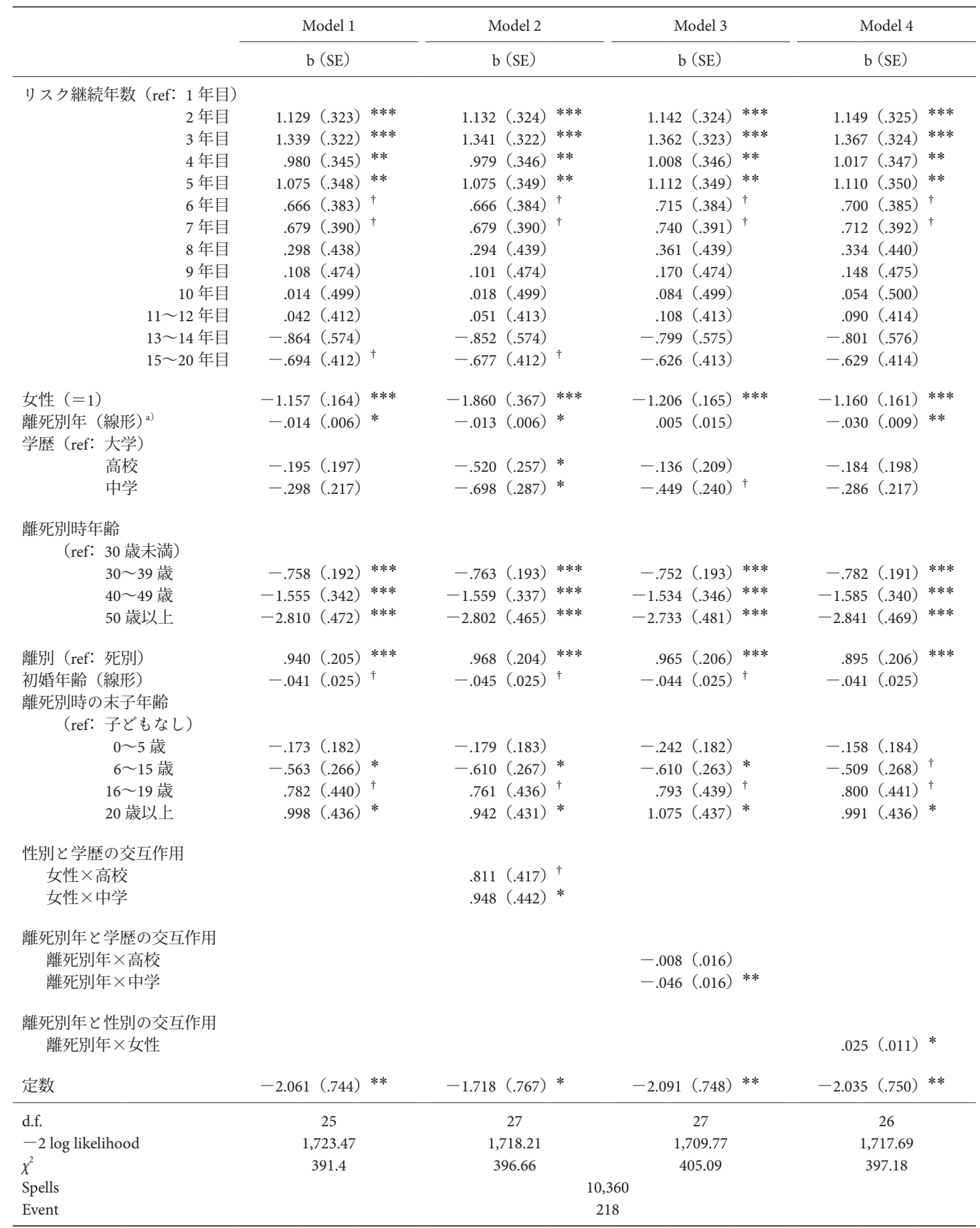

${ }^{\dagger} p<.10,{ }^{*} p<.05,{ }^{* *} p<.01,{ }^{* * *} p<.001$

a) 観測值から平均值を引きセンタリングしている. 


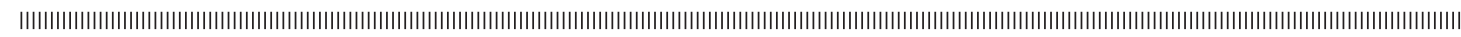

- .520, 中学ダミーがー.698 でいずれも有意であ るが，これらは男性の間での学歴の効果を示して いる。すなわち, 男性の場合, 大卒層は非大卒層 よりも再婚ハザードが有意に高い。一方で女性の 場合, 中学ダミーの係数は-.698+. $948=.250$, 高 校ダミ一の係数は一. $.520+.811=.291$ とそれぞれ 符号はプラスに転じる。しかし，単純傾斜性の検 定（Aiken and West 1991）の結果，女性の間では 学歴の効果は有意ではないことが確認された。し たがって, 男性に限り学歴と再婚ハザードとの間 に正の関連が存在する，という結論に至る。

モデル 3 ならびにモデル 4 は, 再婚率の階層間 格差が離死別コーホート（離死別年）を通じて一 定であるかを検討するためのモデルである．まず モデル 3 では，モデル 1 に離死別年と学歴との交 互作用項を追加している。「離死別年×中学」の 項のみがマイナスに有意であり, 大卒層と中卒層 との間の再婚率の格差は拡大する傾向にあること がわかる。一方で, 大卒層と高卒層との間の差異 は離死別年によって異なるとは言えない.

最後に，モデル 4 では, 離死別年と女性ダミー との交互作用項を共変量に投入したところ，プラ スの有意な効果（ $\mathrm{b}=.025 ）$ を示した. 女性ダミー の主効果は一 1.160 であるが，これは離死別年が 平均值（う1977 年）を取る際の, 男女間の再婚 ハザードの対数オッズ比を表している．「離死別 年×女性ダミ一」の交互作用項はプラスに有意で あるため, 平均的には男性よりも女性のほうが再 婚ハザードが低いが，そのようなジェンダー差は 近年の離死別コーホートほど縮小していることが わかる。

ただし，再婚ハザードのジェンダ一差の縮小は， 離死別した女性が再婚しやすくなったためではな く，男性が再婚しにくくなったことに起因してい る.モデル 4 の結果を別の観点から解釈すれば, 男性の場合，離死別年の係数は一.030 で有意であ るが, 女性の場合, 離死別年の係数は一.030+ $.025=-.005$ となり, 統計的に有意ではない（単 純傾斜性の検定の結果). すなわち, 離死別コー
ホート間で再婚ハザードの低下が生じているの は，男性にのみ当てはまる傾向であると言える。

\section{V. 結論と考察}

本稿では再婚リスクの（1）趨勢，（2）階層差, （3）階層による趨勢の差異について，JGSS20002002 を用いて実証してきた。分析結果は以下の 3 点に要約できる.

第 1 に, 再婚リスクは最近の離死別コーホート ほど低下していた。この傾向は，再婚リスクと離 死別コーホートとのゼロ次の関連（図 2）でも， 離散時間ロジットモデルによる多変量解析の結果 からも確認された。

第 2 に，再婚リスクには階層差が存在し，女性 よりも男性のほうが再婚しやすい，学歴の主効果 は有意ではなかったが, 学歴と性別との間には交 互作用が見られ，男性の間では高学歴層のほうが 低学歴層よりも再婚しやすかった。既存研究では 婚姻行動（初婚・離婚）の社会経済的格差が確認 されてきたが，再婚行動についても男性の間では 同様の知見が当てはまると言える.

最後に, 再婚リスクの趨勢の階層差については 2 つの知見が得られた。第 1 に，再婚リスクの性 差は縮小していた。これは，女性が再婚するよう になったためではなく, 男性の再婚リスクが低下 していることが背景にあった，第 2 に，再婚リス クの学歴間格差は拡大傾向にあり, 学歴と再婚リ スクとの関連は近年の離死別コーホートほど明確 に現れていた。

これらの分析結果を踏まえ，以下ではまず，本 稿の結論として，日本人の婚姻パターンにいかな る変化が生じているのかについて述べる。その 後, なぜ再婚リスクの趨勢変化や階層差が見られ るのかについて考察を加える.

本稿の結果から導出される, 日本人の婚姻パ ターンの変化は「離死別者の非再婚化」である. 個人の観点からすれば，人久はライフコースを通 じて複数回の婚姻関係を経験するようになったわ けではなく, 離死別後に再婚する傾向はむしろ低 
投稿論文：再婚からみるライフコースの変容

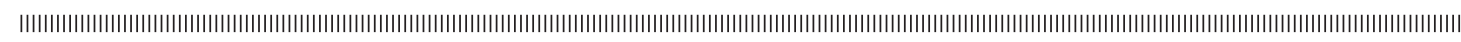

まっていた，確かに，図1に見られるように，日 本社会で再婚がより頻繁に観察されるようになっ たことは間違いない，ただし，その原因は，個人 の再婚傾向が高まったことではなく, 離婚率の高 まりによって再婚のリスク人口が拡大したことに あると推察される。

さらに, 未婚化・晚婚化, 離婚リスクの増大と いった先行研究の知見と合わせて考えれば，無配 偶の状態に滞留するリスクがライフコースを通じ て高まっていると推測される。すなわち，日本人 の婚姻歴を俯瞰すれば，「無配偶期間の長期化」 が進展しているというのが本稿の結論である.

このように, 本稿では再婚リスクの記述的分析 を通じて, 日本人のライフコースの変容を探って きた. その記述的分析の知見は, 先に要約したと おりである。それでは, なぜ最近のコーホートほ ど再婚しないのか, なぜ再婚リスクの性差が縮小 し学歴間格差は広がっているのか. 研究の次のス テップとしては，こうした問いに対する説明的分 析が求められる.

ただし，上記の問いは相互に独立しているわけ ではなく, ある問いに対する回答が得られれば, 自ずと他の問いに対する説明が導出される。まず はその点を整理しておこう。ポイントは, 離死別 者の非再婚化という変化は, 社会全体で一様に広 がっているわけではなく, 階層差を伴っているこ とである. 性差について言えば, 再婚リスクが低 下しているのは男性のみであった。学歴階層の観 点から見れば, 再婚リスクは, 高学歴層では安定 的である一方, 低学歴層では低下していた。さら に, 分析結果は割愛するが, 表 2 のモデル 3 を男 女別に推定すると, 離死別年×学歴の交互作用が 有意になるのは男性のみであった（つまり，女性 の間では再婚リスクの学歴間格差は安定的であ る) ${ }^{(11)}$.したがって, 再婚リスクの全体的な変動 は, 低学歴男性の再婚リスクの低下によるところ が大きいと予想される。

以上を踏まると, 問われるべきは「なぜ低学歴 男性の再婚リスクが低下しているのか」という問
題となる。これに対しては, 仮説の域を出ないも のの, ひとつの説明として,「不安定雇用の増加 による再婚の困難化」というものが考えられる. 非正規雇用をはじめとする不安定雇用の拡大は低 学歴層で著しい. 非正規雇用者の初婚確率が低い ことは指摘されているが（津谷 2009）, 再婚にも 同様の傾向が当てはまる可能性がある，この仮定 が正しければ，低学歴層の再婚リスクの低下は非 正規雇用の増加によって説明される。この仮説を 検証するためには, 離死別後の職業や従業上の地 位を把握する必要があるが, JGSS2000-2002に はそうした情報が含まれていないため, 他の調査 データによる検証が求められる.

なお，再婚率が低下していることは，「人々が 自ら望んで再婚しなくなった」と解釈することも 論理的には可能である。しかしながら, 結婚が社 会経済的（川口 2005）/心理的（稲葉 2002; 中 澤 2010）メリットをもたらすことや ${ }^{(12)}$, 社会経 済的に恵まれた人々の間で離婚リスクが低く再婚 リスクは高いことを踏まえると，再婚率の低下を 単に人々の選好の変化に帰着させることは困難で ある。むしろ, 初婚・再婚にかかわらず婚姻関係 を結ぶチャンスが社会階層によって異なり, 結果 として社会経済的に脆弱な立場の人々が婚姻制度 から排除されつつあるという，ある種の階層問題 が浮かび上がってくるのではないだろうか.

最後に, 今後の課題について述べておくと, 本 稿で得られた知見はいずれも，他の調査データを 用いた追試によって頑健性の確認が必要な段階に あると考えたほうがよいだろう。本稿ではJGSS の累積データを用いたけれども, 再婚のイベント 発生数は決して十分とはいえない.さらに, 繰り 返しになるが，データの制約から，職業や従業上 の地位といった時間依存する共变量と再婚リスク との関連も扱うことができなかった．本稿の分析 結果が示すとおり, 婚姻行動と社会階層とは密接 に結びついており, 家族研究と社会階層研究との 架橋が求められる。これまで, 日本の家族研究・ 社会階層研究では, 婚姻歴に関する詳細な情報を 


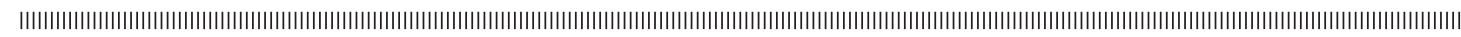

含んだ調査データが不足してきたが，今後は再婚 のみならず婚姻行動と社会階層との関連を検討す ることを視野に入れた社会調査が蓄積されていく ことを期待したい.

\section{【謝辞】}

二次分析にあたり, 東京大学社会科学研究所附属社 会調査・データアーカイブ研究センターSSJ データアー カイブから「日本版 General Social Surveys」(大阪商業 大学比較地域研究所）の個票データの提供を受けた.

\section{【注】}

（1）しかしながら, 再婚の量的増加のみからは, それが家族の多様化の帰結であるのか, 従来 の結婚制度の踏襲の結果であるのかは特定で きない. 家族の多様化に関する Cheal $(2002=$ 2006）の整理を借用すると，仮に再婚の増加 が意味するものが後者であるならば，家族の 「文化的多様化」（個人の選好に基づく家族実 践の結果としての多様化）は進展していない, ということになる.

（2）再婚に関する他の官庁統計として，各年の離 死別者 1,000 人当たりの再婚件数で表される再 婚率がある。しかしこの指標は，ある同時期 に離死別した人々からなる集団が時間の経過 とともにどれほど再婚していくかを捉えたも のではないので, 個人の再婚傾向を測定した ものとはならない.

（3）本稿では「リスク」という用語を繰り返し用 いるが,これはイベントヒストリー分析の慣 例に従ったものである. そのため, リスクと は単に「あるイベントの起きやすさ」という 意味合いであり，そのイベントが望ましくな いことを含意するものではない.

（4）このほかに, 同棲も婚姻パターンの重要な規 定要因であるが，本稿では报わない。

（5）ただし，佐々木（2012）によれば, 初婚に対 する学歴の効果は加齢によって変化し, 全年 齢で見れば高学歴女性は低学歴女性よりも結 婚しにくいものの, 30 歳代の女性に限定すれ ば大卒層のほうが高卒層よりも結婚が生起し やすい。

（6）なお，平均寿命の性差が拡大すれば，女性の 無配偶期間は長期化する。しかし，本稿では 若年期から中年期の婚姻歴に焦点を合わせ， こうした要因は报わない。
（7）パネル調査でも婚姻歴を回顧式で尋ねること は可能であるが，そうして得られた婚姻歴の データはJGSS のような横断調査のそれと本質 的には変わらない。言い換えれば, 回顧式で 測定された「過去の」婚姻歴については，時 間とともに変化する共変量が再婚の生起に及 ぼす影響を検討するというパネル調査の特性 を生かした分析はできない。

（8）この場合，第 2 次大戦期に配偶者と死別した ケースが少なからず存在するため, 何らかの 時代効果が混在する可能性も考えられる。し かし, 分析対象を戦後に離死別した回答者に 限定しても, 分析結果から得られる結論は変 わらなかったため, 今回は分析サンプルの規 模を優先させて, 離死別時期を 1940-99年に 設定した。

（9）分析サンプルにおける出生年の記述統計量は 以下のとおりである. Mean=1939.0, SD=14.0, $\operatorname{Min}=1911, \operatorname{Max}=1977$.

（10）ただし，このような再婚ハザードの時間依存 が真に離死別後の時間経過の効果を示したも のであるのかは断言できず，「観察されない異 質性」（Yamaguchi 1991）によるものである可 能性も存在するため, ここでは特に解釈しな い.

（11）男女込みのデータセットを用いて「離死別年メ 学歴×性別」の交互作用を含んだモデルを推 定した結果からも，再婚リスクの学歴間格差 が拡大しているのは男性のみであることを確 認できる（紙幅の都合上，分析結果は割愛）.

（12）川口（2005）によれば，結婚は男性賃金に正 の効果（結婚プレミアム）を持つ一方で，女 性貨金には負の効果（結婚ペナルティ）を持 つ、しかしながら，世帯単位で見れば有配偶 女性は無配偶女性（特に離死別者）よりも経 済状況が良い（Tanaka 2013）。

\section{【文献】}

阿部彩，2008，『子どもの貧困一日本の不公平を考え る』岩波書店.

Aiken, Leona S. and Stephen G. West, 1991, Multiple Regression: Testing and Interpreting Interactions, Newbury Park, California: Sage Publications.

Cheal, David J., 2002, Sociology of Family Life, Basingstoke: Palgrave Macmillan. (野々山久也監訳, 2006, 『家族ラ イフスタイルの社会学』ミネルヴァ書房).

福田亘孝，2006，「ライフ・コースは多様化している 
投稿論文：再婚からみるライフコースの変容

|||||||||||||||||||||||||||||||||||||||||||||||||||||||||||||||||||||||||||||||||||||||||||||||||||||||||||||||||||||||||||||||||||||||||||||||||||||||||||||||||||||||||||||||||||||||||||||||||||||||||||||||||||||||||||||||||||||||||||||||||||||||||||||-||-||-||

か? ——最適マッチング法によるライフ・コース分

析」西野理子・稲葉昭英・嶋㠃尚子編『第 2 回家族 についての全国調査（NFRJ03）第 2 次報告書 No. 1: 夫婦, 世帯, ライフコース』日本家族社会学会全国 家族調查委員会, 167-81.

，2009，「配偶者との別れと再びの出会い-

離別と死別，再婚」藤見純子・西野理子編『現代日 本人の家族』有斐閣, 72-84.

福田節也, 2005, 「離婚の要因分析」財団法人家計経済 研究所編『リスクと家計 消費生活に関するパネル 調査一一平成 17 年版』国立印刷局, 49-63.

稲葉昭英, 2002,「結婚とディストレス」『社会学評論』 53(2): 69-84.

加藤彰彦, 2001, 「未婚化・社会階層 - 経済成長」『家 族社会学研究』13(1): 47-58.

一，2004, 「未婚化・晚婚化と社会経済的状況」 渡辺秀樹 - 稲葉昭英 - 嶋㠃尚子編『現代家族の構造 と変容—全国家族調査（NFRJ98）による計量分析』 東京大学出版会, 41-58.

— , 2005, 「離婚の要因：家族構造・社会階層・ 経済成長」熊谷苑子・大久保孝治編『コーホート比 較による戦後日本の家族変動の研究 (全国調查「戦 後日本の家族の歩み」（NFRJ-S01）報告書 No. 2)』日 本家族社会学会全国家族調査委員会, 77-90.

川口章, 2005,「結婚と出産は男女の賃金にどのような 影響を及ぼしているのか」『日本労働研究雑誌』 47 (1): 42-55.

目黒依子，1987，『個人化する家族』勁草書房.

永井暁子, 2010, 「未婚化社会における再婚の増加の意

味」佐藤俊樹・永井暁子・三輪哲編『結婚の壁—
非婚・晚婚の構造』勁草書房, 172-82.

中澤渉, 2010,「男女間のメンタルヘルスの変動要因の

違いに関する分析」東京大学社会科学研究所パネル 調査プロジェクトディスカッションペーパーシリー ズ No. 31 .

野々山久也，1996，「家族新時代への胎動——家族社会 学のパラダイム転換にむけて」野々山久也・袖井孝 子・篠崎正美編『いま家族に何が起こっているのか —家族社会学のパラダイム転換をめぐって』ミネ ルヴァ書房, 285-305.

Peterson, Richard R., 1996, “A Re-evaluation of the Economic Consequences of Divorce," American Sociological Review, 61(3): 528-36.

佐々木尚之, 2012,「不確実な時代の結婚一JGSS ライ フコース調査による潜在的稼得力の影響の検証」『家 族社会学研究』24(2): 152-64.

白波瀬佐和子，1999,「女性の高学歴化と少子化に関す る一考察」『人口問題研究』34(4): 392-401.

Tanaka, Sigeto, 2013, “Gender Gap in Equivalent Household Income after Divorce," Tanaka Sigeto ed., A Quantitative Picture of Contemporary Japanese Families: Tradition and Modernity in the 21st Century, Sendai: Tohoku University Press, 321-50.

津谷典子, 2009, 「学歴と雇用安定性のパートナーシッ プ形成への影響」『人口問題研究』65(2): 45-63.

Yamaguchi, Kazuo, 1991, Event History Analysis, Newbury Park, California: Sage Publications.

渡邊勉, 2004,「職歴パターンの分析——最適マッチン グ分析の可能性」『理論と方法』19(2): 213-34. 